\title{
Cold Plasma and Acid Treatment Modification Effects on Phonolite
}

\section{José Miguel Hidalgo-Herrador,* Zdenĕk Tišler, Pavlína Hajková, Lenka Soukupová, Lenka Zárybnická and Karla Černá}

Unipetrol Centre for Research and Education / UNICRE, Areál Chempark, 436 70, Litvínov-Záluží 1, Czech Republic.

* Corresponding author: E-mail: jose.hidalgo@ unicre.cz

Received: 06-03-2017

\begin{abstract}
A sample of phonolite was treated by cold plasma and hydrochloric acid diluted in water to study the change of its structure and acid properties. The phonolite and treated samples were analysed by XRD, elemental analysis XRF, specific surface area BET, TPD-NH $\mathrm{N}_{3}$ and FT-IR spectroscopy. They were also tested in the adsorption of $\mathrm{Ca}, \mathrm{K}, \mathrm{Mg}, \mathrm{P}$ and $\mathrm{Na}$ impurities present in waste cooking oil. Plasma treated sample presented almost the same structure with some surface differences respect to the original phonolite. However, acid treated sample presented bigger total surface compared to the other samples, different structure, composition and acid properties.
\end{abstract}

Keywords: phonolite, cold plasma, acid treatment, structure modification, adsorption

\section{Introduction}

Phonolite is an igneous rock formed composed mainly by alkali feldspar and other compounds. ${ }^{1}$ Many works were published about phonolite but they were based mainly in geology, geochemistry or mineralogy. Nevertheless, a lower number of publications were found about the experimental modification of the structure of phonolite. However, some experiments were carried out with the aim of studying the structure modifications of new solids obtained at high temperature and pressure. ${ }^{2-5}$ Acid treatment of solids has been extensively studied for many applications such as catalysis, agriculture, membranes, etc. This treatment could be an effective tool to modify the structure and composition of the phonolite. ${ }^{1}$ Acid treatment could be an advantage increasing the porosity of the material for using it as adsorbent or catalyst as described for other type of materials. ${ }^{6}$ Also, it could be a disadvantage as $\mathrm{K}^{+}$donor material for being used as fertilizer. ${ }^{7}$ Nevertheless, no previous publications were found about the acid treatment effects on phonolite structure. Another treatment for the modification of solids is the plasma application which has been used for modifying the adsorbent surfaces ${ }^{8-10}$ Plasma is classified as cold plasma when the temperature used is lower than $500{ }^{\circ} \mathrm{C}$. The advantages of this treatment are clean reaction and a short processing time without affec- ting the bulk structure. ${ }^{11,12}$ However, this treatment could also be a disadvantage for changing its bulk structure. Some studies using cold plasma were published. ${ }^{11-15} \mathrm{Ne}-$ vertheless, no studies have been reported on the modification of phonolite using this methodology. This paper is the first study on the modification of phonolite using cold plasma and acid treatment. The aim of this work was to study the modification of the phonolite by using two separate processes (surface modification by cold plasma and structure change by acid treatment).

\section{Experimental}

The phonolite $(\mathrm{Ph})$ was supplied in powder form by the company Keramost a. s. ${ }^{16} \mathrm{Ph}$ sample $(20 \mathrm{~g})$ was dried at $120^{\circ} \mathrm{C}$ overnight. Then, it was leached by $3 \mathrm{M} \mathrm{HCl}$ solution $\left(80^{\circ} \mathrm{C}\right.$ for $4 \mathrm{~h}$ ). The phonolite:acid (g:ml) ratio was 1:10. After the leaching process, the product was filtered, washed (by several times with hot demineralised water) and dried overnight at $120{ }^{\circ} \mathrm{C}$. Finally, the dried samples were calcined at $500{ }^{\circ} \mathrm{C}$ during $6 \mathrm{~h}$ (gradient $1{ }^{\circ} \mathrm{C} / \mathrm{min}$ from room temperature) in air obtaining the acid treated phonolite (A-Ph). The plasma treated phonolite (CP-Ph) was synthesized by nonthermal DBD plasma which was conducted in ambient air (humidity $32 \%$ ) at atmospheric 
pressure and the discharges were operated in filamentary mode (they were constituted by a high amount of tiny micro discharges randomly distributed over the entire area of the electrodes). The plasma reactor consisted of two plane parallel electrodes covered with a $1 \mathrm{~mm}$ layer of dielectric. The upper electrode $(105 \times 20 \times 12 \mathrm{~mm})$ was covered with corundum and the bottom electrode $(120 \times 60 \times 20$ $\mathrm{mm}$ ) with a mobile rubber providing transport of the material at the same time. The distance between the electrodes was $4 \mathrm{~mm}$. Plasma treatment conditions and parameters were: AC source voltage $20 \mathrm{kV}$, frequency $3 \mathrm{kHz}$, nominal power $120 \mathrm{~W}$, modification time periods $5 \mathrm{~s}$. XRF, $\mathrm{XRD}$, specific surface area BET and $\mathrm{NH}_{3}$ temperature programmed desorption (TPD- $\mathrm{NH}_{3}$ ) were carried out using the same methodology described in the literature. ${ }^{17}$ Mercury porosimetry measurements were performed on a Micromeritics AutoPore IV 9510 mercury porosimeter. All samples were dried before the analysis in a glass-cell at $110{ }^{\circ} \mathrm{C}$ under vacuum for 16 hours. Attenuated total reflectance technique (ATR) using an instrument Nicolet iS 10-Thermo Scientific (crystal diamond; number of scans $=64$; resolution $4 \mathrm{~cm}^{-1}$ ) was used for the FT-IR measurements. The scanning electron microscopy (SEM) was carried out using a Zeiss ULTRA Plus microscope equipped with Oxford detector for energy-dispersive analysis (EDX). Finally, the samples were tested in the adsorption of $\mathrm{Ca}, \mathrm{Mg}, \mathrm{K}, \mathrm{P}$ and $\mathrm{Na}$ in waste cooking oil (WCO). The adsorption procedure was carried out using $20 \mathrm{~g}$ of filtered WCO which was previously heated at $95^{\circ} \mathrm{C}$. Then, $2 \mathrm{~g}$ of sorbent (phonolite) were added. The mixture was stirred during 1 hour at room temperature and filtered. Finally, the liquid product was analyzed by the instrument ICPOES/Agilent 725. The WCO elemental composition was $78 \%$ wt. of carbon, $11.9 \%$ wt. of hydrogen, $0.387 \mathrm{mg} \mathrm{kg}^{-1}$ of $\mathrm{Ca}, 0.104 \mathrm{mg} \mathrm{kg}^{-1}$ of $\mathrm{Mg}, 1.02 \mathrm{mg} \mathrm{kg}^{-1}$ of $\mathrm{K}, 2.04 \mathrm{mg}$ $\mathrm{kg}^{-1}$ of $\mathrm{P}, 1.82 \mathrm{mg} \mathrm{kg}^{-1}$ of Na, $4.13 \mathrm{mg} \mathrm{kg}^{-1}$ of sulfur and $64.2 \mathrm{mg} \mathrm{kg}^{-1}$ of nitrogen content. The supplied WCO presented a total acid number of $2 \mathrm{mg} \mathrm{KOH} \mathrm{g}{ }^{-1}$.

\section{Results and Discussion}

As shown in XRF results, practically no changes were found for samples $\mathrm{Ph}$ and $\mathrm{CP}-\mathrm{Ph}$ (Table 1). Sample A-Ph presented higher $\mathrm{Si}$ and lower $\mathrm{Al}, \mathrm{Na}$ and $\mathrm{K}$ contents respect to the $\mathrm{Ph}$ sample. The acid treatment implied an increment in the total porosity as consequence of the removing of $\mathrm{Al}, \mathrm{Na}$ and $\mathrm{K}$. Also, the content of $\mathrm{Fe}$ and $\mathrm{Ca}$ decreased for $\mathrm{A}-\mathrm{Ph}$ respect to the $\mathrm{Ph}$ sample.

Almost identical $\mathrm{Hg}$ porosimetry results were found for $\mathrm{Ph}$ and $\mathrm{CP}-\mathrm{Ph}$ samples with a low total porosity. No mesopores and a minimum number of micropores were detected in these samples. Acid treatment supposed an increment in the total porosity. The increment of the porosity in the 3-30 $\mathrm{nm}$ range (mesopores) was an interesting result taking in account possibly future applications of this material as catalyst or absorbent for large molecules. Nevertheless, BET specific surface showed a bigger specific surface compared than the total pore area by $\mathrm{Hg}$ porosimetry (table 1 ) indicating the presence of a high number of micropores. The acid treatment also implied an increment in the total intrusion volume of the sample mainly due to the macropores volume.

XRD results informed about a similar content of analcime $25.2 \%$, nepheline $42.9 \%$ and sanidine $31.9 \%$ in samples $\mathrm{Ph}$ and $\mathrm{CP}-\mathrm{Ph}$. However, a change in the structure-composition was found for the A-Ph sample with $41.7 \%, 14.9 \%, 1.2 \%$ and $42.3 \%$ of sanidine, nepheline, analcime and albite respectively. Surely, these changes were produced mainly by the removing of $\mathrm{Al}, \mathrm{Na}$ during the acid treatment process of the original phonolite as reflected in the elemental composition.

For FT-IR results, some bands were identified between 1200 and $650 \mathrm{~cm}^{-1}$ which were related to bond stretchings of $\mathrm{Si}-\mathrm{O}-\mathrm{Si}$ or $\mathrm{Si}-\mathrm{O}-\mathrm{Al}$, due to the presence of silicon and aluminium oxides. The treatment of each sample at $100{ }^{\circ} \mathrm{C}$ removed the possible content of water

Table 1. Elemental XRF Composition and surface area.

\begin{tabular}{|c|c|c|c|}
\hline Material & $\mathbf{P h}$ & CP-Ph & A-Ph \\
\hline Specific Surface BET $\left(\mathrm{m}^{2} \mathrm{~g}^{-1}\right)$ & 4.9 & 8 & 167 \\
\hline Hg porosimetry / Total pore area $\left(\mathrm{m}^{2} \mathrm{~g}^{-1}\right)$ & 1.7 & 2.3 & 34 \\
\hline Composition & (\%wt.) & (\%wt.) & $(\%$ wt. $)$ \\
\hline$\overline{\mathrm{Si}}$ & 26.5 & 26.5 & 38.6 \\
\hline $\mathrm{Al}$ & 11.8 & 11.9 & 4.5 \\
\hline $\mathrm{Na}$ & 7.9 & 7.9 & 1.7 \\
\hline K & 5.1 & 5.1 & 4.3 \\
\hline $\mathrm{Fe}$ & 1.4 & 1.3 & 0.6 \\
\hline $\mathrm{Ca}$ & 0.7 & 0.7 & 0.1 \\
\hline $\mathrm{Cl}$ & 0.3 & 0.4 & 0.1 \\
\hline $\mathrm{Ti}$ & 0.2 & 0.2 & 0.1 \\
\hline${ }^{1}$ Calculated sum & 99.4 & 99.4 & 99.6 \\
\hline
\end{tabular}

${ }^{I}$ Total sum of theoretically present $\mathrm{SiO}_{2}, \mathrm{Al}_{2} \mathrm{O}_{3}, \mathrm{Na}_{2} \mathrm{O}, \mathrm{K}_{2} \mathrm{O}, \mathrm{Fe}_{2} \mathrm{O}_{3}, \mathrm{CaO}, \mathrm{Cl}$ and $\mathrm{TiO}_{2}$. 
in the samples. Thus, no representative bands between 3650 and $3200 \mathrm{~cm}^{-1}$ related to the vibration stretching of $\mathrm{OH}$ bond were found. ${ }^{5,18}$ However, the $\mathrm{OH}$ vibration stretching also could be due to the $\mathrm{OH}$ present in minerals. So, a low content of hydroxides is expected for the surface of these solids. The cold plasma treatment could modified slightly the surface of the phonolite as shown in a more intensive band at $850-1150 \mathrm{~cm}^{-1}$ for sample $\mathrm{Ph}$ compared to $\mathrm{CP}-\mathrm{Ph}$. The biggest change was found for the $\mathrm{A}-\mathrm{Ph}$ sample. The lost of intensity in the bands range of $650-1300 \mathrm{~cm}^{-1}$ was surely due to a lower amount of $\mathrm{Si}-\mathrm{O}-\mathrm{Si}$ and/or Si-O-Al bonds type. A-Ph sample contained less Al than the other samples so it could be reason of the lowest intensity band. The difference between samples $\mathrm{Ph}$ and $\mathrm{CP}-\mathrm{Ph}$ could be explained by the change of Si-O-Al to other type of bonds which could affect the acidity of the sample.

For the TPD- $\mathrm{NH}_{3}$ characterization (Fig. 1), all materials showed a broad $\mathrm{NH}_{3}$ desorption peak stretched in a wide range from 175 to $350^{\circ} \mathrm{C}$ corresponding to the intermediate and stronger acid sites. The characteristics and the amount of acid sites varied when the phonolite was treated. $\mathrm{CP}-\mathrm{Ph}$ presented slightly lower intensity in the signal related to the intermediate and strong acid sites and the same intensity than $\mathrm{Ph}$ for the weak acid sites. A-Ph

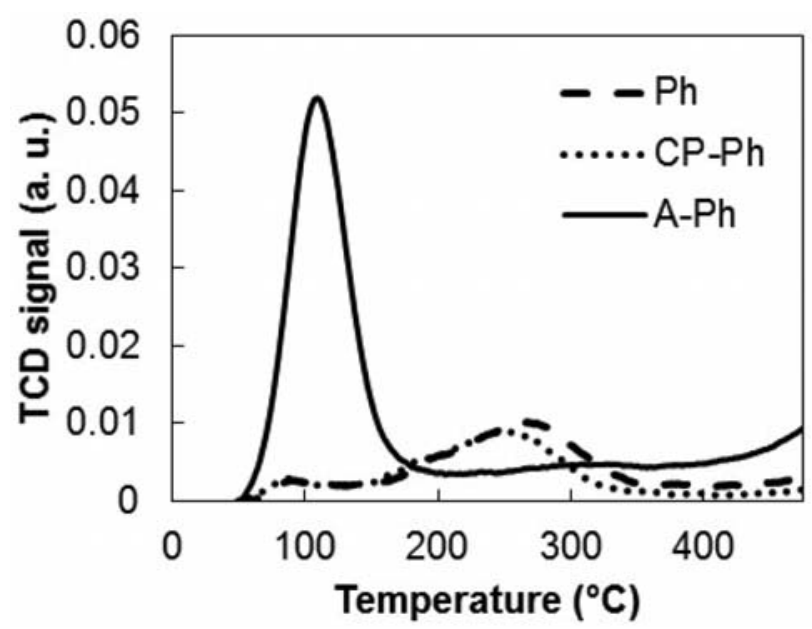

Fig. 1. TPD- $\mathrm{NH}_{3}$ for $\mathrm{Ph}, \mathrm{CP}-\mathrm{Ph}$ and $\mathrm{A}-\mathrm{Ph}$ samples. $100 \mathrm{mg}$ of sample was pre-treated in $\mathrm{He}$ at $500{ }^{\circ} \mathrm{C}$, cooled to $180^{\circ} \mathrm{C}$ and finally saturated with ammonia. Then, the temperature was increased to $500{ }^{\circ} \mathrm{C}$ with a rate of $15{ }^{\circ} \mathrm{C} / \mathrm{min}$. sample presented the highest number of weak acid sites (peak at $100^{\circ} \mathrm{C}$ ) as consequence of the removing of $\mathrm{Al}$ instead of a higher \% of Si present in the surface of the solid. Thus, the acid treatment implied an increment in the total number of weak acid sites and the cold plasma treatment slight decrease in the number of intermediate and stronger acid sites.

WCO adsorption test results (Table 2) were different depending on the type of adsorbent used. When the oil was treated with $\mathrm{Ph}$, the filtered product presented higher $\mathrm{Ca}, \mathrm{K}$ and $\mathrm{Na}$ contents. However, the content of $\mathrm{P}$ was a half from the original WCO content, for the oil treated with $\mathrm{Ph}$. CP-Ph oil treatment supposed a clear increment of $\mathrm{K}$ and $\mathrm{Na}$ in the final oil. Only the treatment using $\mathrm{A}-\mathrm{Ph}$ solid supposed a decrease in $\mathrm{Ca}, \mathrm{Mg}, \mathrm{K}, \mathrm{P}$ and $\mathrm{Na}$ in the oil. $\mathrm{CP}-\mathrm{Ph}$ oil treatment test results informed about a bigger increment of $\mathrm{K}$ and $\mathrm{Na}$ compounds in the oil respect to the results from the treated oil with $\mathrm{Ph}$. These different results could be attributed only to the different surface of $\mathrm{Ph}$ and $\mathrm{CP}-\mathrm{Ph}$ because the two solids presented similar elemental composition and XRD results. Thus, A-Ph was the only solid, which actuated as absorber and not as donor of $\mathrm{Ca}, \mathrm{Mg}, \mathrm{K}, \mathrm{P}$ and $\mathrm{Na}$ in these tests.

SEM images (Fig. 2) of $\mathrm{Ph}$ and $\mathrm{CP}-\mathrm{Ph}$ showed particles of approximately 5-20 $\mu \mathrm{m}$ size ratio in diameter with different forms. For sample A-Ph, the particle size was in the 5-40 $\mu \mathrm{m}$ range. The differences are not clear between the $\mathrm{Ph}$ and $\mathrm{CP}-\mathrm{Ph}$ samples. Nevertheless, sample A-Ph presented a clear difference in its surface respect to the original phonolite.

The same sample of phonolite was treated three times (acid and plasma treatments) and the resultant XRF, $\mathrm{XRD}$ and $\mathrm{Hg}$ porosimetry measurements presented almost the same results (XRF elemental composition with a percentage error lower than $0.5 \%$ ). The adsorption procedure was repeated three times presenting similar results for the elemental analyses with a percentage error lower than $1 \%$ ( $\mathrm{Ca}, \mathrm{Na}$, sulphur, $\mathrm{Mg}, \mathrm{K}$ and nitrogen contents).

\section{Conclusions}

The phonolite was modified by acid and cold plasma treatments. Then, it was tested in a WCO absorption test. The cold plasma treatment supposed a modification of the

Table 2. Ca, Mg, K, P and Na contents in WCO treated samples with $\mathrm{Ph}, \mathrm{CP}-\mathrm{Ph}$ and A-Ph.

\begin{tabular}{lcccc}
\hline Parametr & Oil-Feedstock & Oil/Ph & Oil/CP-Ph & Oil/A-Ph \\
$\mathrm{Ca}\left[\mathrm{mg} \mathrm{kg}^{-1}\right]$ & 0.39 & 1.07 & 1.56 & 0.25 \\
$\mathrm{Mg}\left[\mathrm{mg} \mathrm{kg}^{-1}\right]$ & 0.10 & 0.09 & 0.23 & 0.04 \\
$\mathrm{~K}\left[\mathrm{mg} \mathrm{kg}^{-1}\right]$ & 1.02 & 2.14 & 7.53 & 1.00 \\
$\mathrm{P}\left[\mathrm{mg} \mathrm{kg}^{-1}\right]$ & 2.04 & 1.33 & 1.5 & 1.07 \\
$\mathrm{Na}\left[\mathrm{mg} \mathrm{kg}^{-1}\right]$ & 1.82 & 3.56 & 5.15 & 1.25 \\
\hline
\end{tabular}

Hidalgo-Herrador et al.: Cold Plasma and Acid Treatment Modification ... 
a)
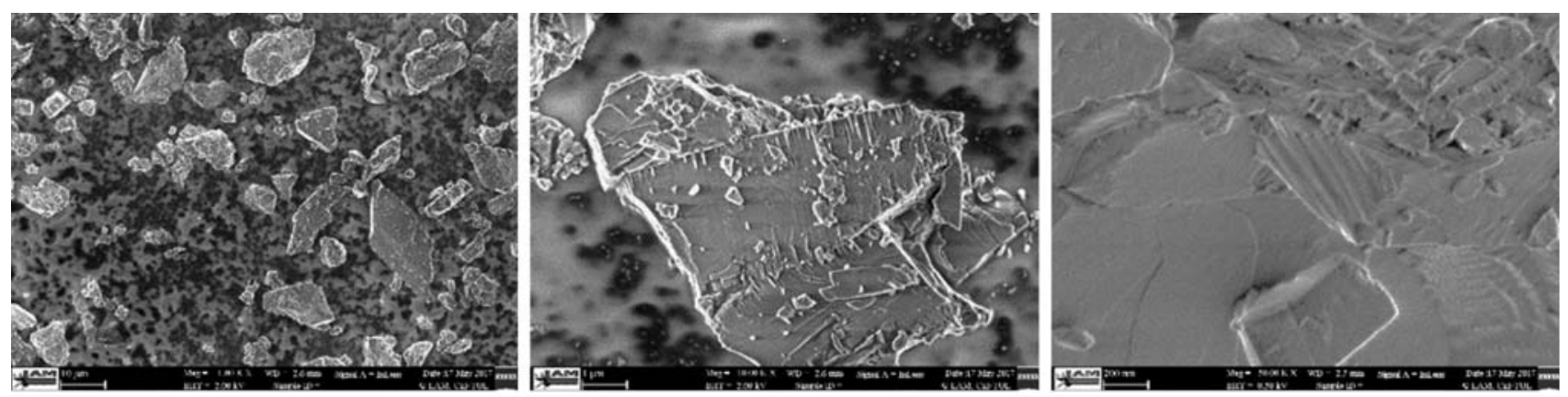

b)
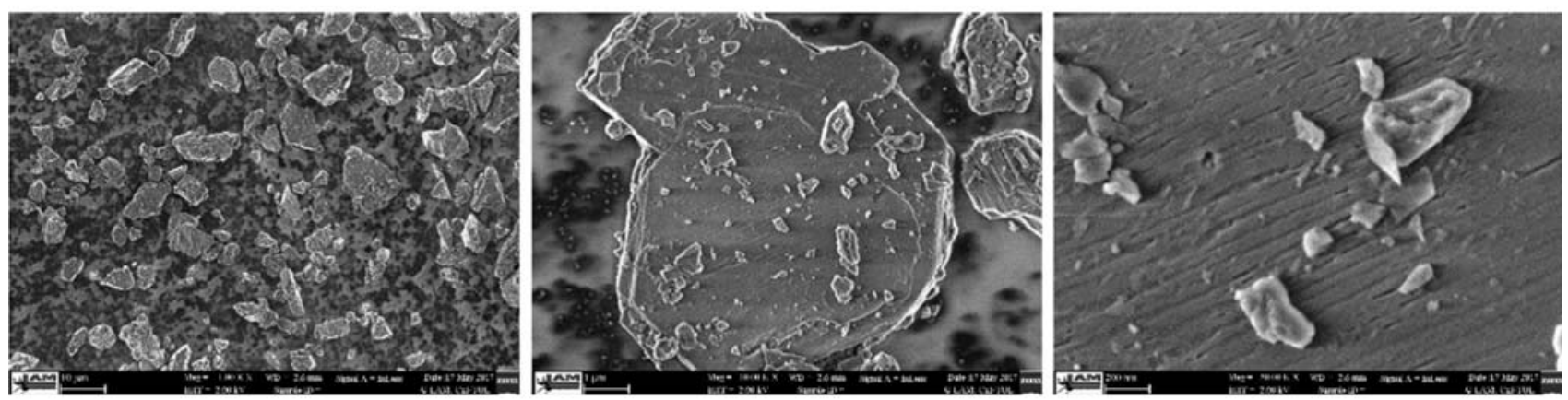

c)
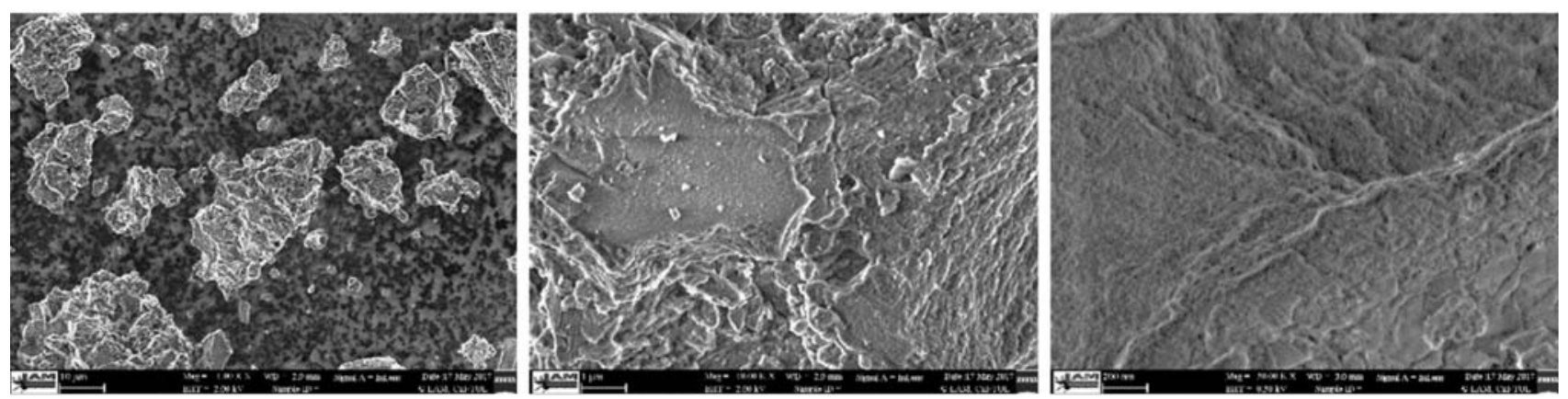

Fig. 2. SEM images. (a) Ph (x1,000, x10,000 and x50,000); (b) CP-Ph (x1,000, x10,000 and x50,000); (c) A-Ph (x1,000, x10,000 and x50,000).

original $\mathrm{Ph}$ surface and the acid treatment supposed a change in the original $\mathrm{Ph}$ structure and composition changing dramatically its total surface and acid properties. For the WCO tests, A-Ph sample absorbed the biggest amount of $\mathrm{Ca}, \mathrm{Mg}, \mathrm{K}, \mathrm{P}$ and $\mathrm{Na}$. This work could be the beginning of another new generation of materials, which could be used in many current applications.

\section{Acknowledgements}

The publication/presentation is a result of the Project Development of the UniCRE Centre (Project Code LO1606) which was financially supported by the Ministry of Education, Youth and Sports of the Czech Republic under the National Programme for Sustainability I.

\section{Supplementary Material}

The document contains the XRD, Hg isotherms, FTIR figures and some more detailed information about TPD- $\mathrm{NH}_{3}$ and SEM experimental procedures.

\section{References}

1. Imperial College Rock Library, Glossary: Phonolite. Imperial College London, South Kensington Campus, London SW7 2AZ. Web link accessed on 02/14/2017. Web link: https://wwwf.imperial.ac.uk/earthscienceandengineering/rocklibrary/viewglossrecord.php?Term=phonolite

2. Y. Moussallam, C. Oppenheimer, P. Scaillet, R. Kyle, $J$ Petrology 2013, 54, 1285-1307.

https://doi.org/10.1093/petrology/egt012 
3. V. A. Kutolin, V. A. Shirokih, Tailings and mine waste reprocessing for production of the foamed glass, 5th Annual International Conference on Tailings and Mine Waste, Colorado State Univ., Ft. Collins, Civil Engineering, Geotech Engineering Program, Tailings and mine waste 98, (Jan 26-28, 1998) 909-916. Edited by J.D. Nelson.

4. J. L. Capitaneo, F. T. Silva, C. M. F. Vieira, Silic. Ind. 2005, $70,161-165$

5. A. M. S. Teixeira, F. M. S. Garrido, M. E. Medeiros, J. A. Sampaio, Int. J. Miner. Process. 2015, 145, 57-65. https://doi.org/10.1016/j.minpro.2015.07.002

6. S. Morin, A. Berreghis, P. Ayrault, N. S. Gnep, M. Guisnet, J. Chem. Soc. Faraday Trans. 1997, 93, 3269-3275. https://doi.org/10.1039/a702538f

7. K. von Wilpert, M. Lukes, Nutr. Cycl. Agroecosys. 2003, 65, 115-127. https://doi.org/10.1023/A:1022103325310

8. N. Celini, F. Poncin-Epaillard, F. Bergaya, Polymer 2007, 48, 58-67. https://doi.org/10.1016/j.polymer.2006.11.018

9. G. Le Du, N. Celini, F. Poncin-Epaillard, F. Bergaya, Surf. Coat. Technol. 2006, 201, 5815-5821. https://doi.org/10.1016/j.surfcoat.2006.10.025

10. C. Saka, O. Şahin, Color. Technol. 2011, 127, 246-255. https://doi.org/10.1111/j.1478-4408.2011.00306.x
11. K. F. Grythe, F. K. Hansen, Langmuir 2006, 22, 6109-6124. https://doi.org/10.1021/la053471d

12. M. Lehocky, H. Drnovska, B. Lapcikova, A. M. BarrosTimmons, T. Trindade, M. Zembala, L. Jr. Lapcik, Colloids Surf. A 2003, 222, 125-131.

13. Ö. S̨ahin, M. Kaya, C. Saka, Appl. Clay Sci. 2015, 116, 46-53. https://doi.org/10.1016/j.clay.2015.08.015

14. M. Kaya, M. F. Dilekoğlu, Ö S̨ahin, C. Saka, Plasma Chem. Plasma Process. 2016, 36, 1417-1430. https://doi.org/10.1007/s11090-016-9745-y

15. O. Yavuz, C. Saka, Appl. Clay Sci. 2013, 85, 96-102. https://doi.org/10.1016/j.clay.2013.09.011

16. Phonolite supplied by the company Keramost. Web link accesed on 05/31/2017. Web link: http://www.keramost.cz/en/products/-/phonolite

17. J.M. Hidalgo, Z. Tišler, D. Kubička, K. Raabova, R. Bulanek, J. Mol. Catal. A Chem. 2016, 420, 178-189. https://doi.org/10.1016/j.molcata.2016.04.024

18. R. L. Frost, A. López, F. L. Theiss, A. W. Romano, R. Scholz, Spectrochim. Acta A Mol. Biomol. Spectrosc. 2014, $133,521-525$.

https://doi.org/10.1016/j.saa.2014.06.034

\section{Povzetek}

Vzorce fonolita smo obdelovali v hladni plazmi in razredčeni klorovodikovi kislini ter preučevali vpliv postopkov na strukturo in kislinske lastnosti. Analizirali smo jih z naslednjimi metodami: rentgensko praškovno difrakcijo (XRD), elementno analizo (rentgensko fluorescenčno spektrometrijo XRF), meritvami specifične površine (BET), temperaturno programirano desorpcijo $\mathrm{NH}_{3}\left(\mathrm{TPD}-\mathrm{NH}_{3}\right.$ ) in infrardečo spektroskopijo (FT-IR). Preizkušali smo tudi primernost vzorcev za adsorpcijo nečistoč $\mathrm{Ca}, \mathrm{K}, \mathrm{Mg}, \mathrm{P}$ in Na iz odpadnega jedilnega olja. Vzorci, ki smo jih obdelali v plazmi, so imeli glede na začetno stanje skoraj enako strukturo z nekaj razlikami na površini. Večji vpliv je imelo obdelovanje s kislino. V tem primeru se je povečala površina vzorca, spremenila njegova struktura in sestava ter kislinske lastnosti. 